\title{
The limits of coexistence: the development of "frugal" systems in agro-pastoral regions
}

\section{Nadège Garambois ${ }^{1}$ (D) Claire Aubron ${ }^{2} \cdot$ Nathan Morsel $^{1} \cdot$ Myriam Latrille $^{2}$. Lucien Jallot ${ }^{1} \cdot$ Valentin Lhoste $^{2}$}

Received: 6 March 2019 / Accepted: 15 May 2020 / Published online: 29 June 2020

(C) INRAE and Springer-Verlag France SAS, part of Springer Nature 2020

\begin{abstract}
Since the 1950s, the development of livestock farming in France has focused on a technical model aimed at constantly increasing the physical productivity of labour, to the detriment of value creation. A comparative study of four small agro-pastoral regions illustrates the consequences of this development model in the geographical context: falling numbers of agricultural jobs and an ebb in the share of grazing in the diet of flocks, resulting in underuse or abandon of the areas deemed most difficult, which has in turn led to closure of landscapes. Alternatives have, however, emerged, some of which seek to create more value through a frugal functional model based conversely on greater use of pastoral resources, promoting more sustainable agriculture. The limited development of these frugal agro-pastoral systems is analysed here, with the aim of identifying areas of competition and the limits of coexistence between agricultural development models.
\end{abstract}

Keywords Agro-pastoral farming · Frugal system · Comparative agriculture · Agricultural development $\cdot$ Productivity

\section{Introduction}

Since the 1950s, the development of livestock farming in France has focused on a technical model aimed at constantly increasing the physical productivity of labour (Charroin et al. 2012; Devienne 2019). This phenomenon is particularly strong in plain regions, although it is also observed in mid-size mountain areas and foothills (MacDonald et al. 2000; Aubron et al. 2016). These regions are often described as

Nadège Garambois

nadege.garambois@agroparistech.fr

1 AgroParisTech, Paris, France

2 Montpellier SupAgro, Paris, France 
agro-pastoral, referring to the surface occupied by rangelands (woodlands, heathlands, grasslands, permanent pastures, etc.) in farms. This shift has, however, taken place under less favourable conditions than on the plains. Altitude and reliefs explain the presence of ecosystems which might be less adapted to this increase of physical productivity of labour, and sometimes a more difficult access both to industrial equipment for the processing of agricultural products and to markets.

This study in several small agro-pastoral regions aims to improve understanding of how this predominant agricultural model has been applied in regions that are at a comparative disadvantage, while also looking at alternatives that have emerged and analysing the prospects for such alternatives today. On the scale of these small agricultural regions, the study also explores the three fields defined by Le Velly (2017) for studying alternative food systems: (i) characterization of "conventional" and "alternative" systems in their diversity and hybrid forms; (ii) effects of alternative food systems; and (iii) tensions in the relationship between "alternative" and "conventional" systems. The study and comparison of these different development models, be they conventional or alternative, along with the technical and economic dynamics underpinning each and their access to agricultural policies support, market exchanges and technical support services, raise questions regarding the conditions and limitations of their coexistence.

Four small agro-pastoral regions have been selected (Fig. 1). Causses (1), the Cévennes valleys (2) and Chartreuse (3) illustrate contrasted climatic contexts (a strong Mediterranean influence for the first two and a mountain climate with abundant and regular rain for Chartreuse) and different productive specialities (dairy and suckler ewe farming, dairy goat farming and dairy cow farming). The region Avant-Causse and its foothills (4), meanwhile, is subject to Mediterranean influences but has very varied climate and soil conditions and pastoral resources. It is home to farms primarily raising dairy ewes and dairy goats. Causses and Cévennes were chosen because of their emblematic agro-pastoral nature, which earned them UNESCO World Heritage status in 2011; Avant-Causse and its foothills and Chartreuse because both have a group of farmers $\left(\mathrm{CIVAM}^{1}\right.$ Empreinte and $\mathrm{ADDEAR}^{2}$ Isère) who, contrary to the predominant development model, have chosen to move away from seeking an increase in production per worker. For the last decade or so, they have been working to implement systems they describe as "frugal", which seek to reduce expenditure on intermediate consumption and equipment through greater use of grazing, with the key goal of supporting more agricultural jobs.

This work uses a comparative agriculture approach (Cochet et al. 2007; Cochet 2015). The analysis at the scale of a small agricultural region provides an understanding of the agricultural development processes characteristic of the region, placing them in given agro-ecological and socio-economic contexts. It is also at this scale that any functional synergies between farms come into play, as well as competition in access to resources and markets (land, public-sector support, agricultural advisers, local markets, etc.) (Galliano et al. 2017), and that comparative analysis of differentiation processes

\footnotetext{
${ }^{1}$ CIVAM, Centre d'Initiative pour Valoriser l'Agriculture et le Milieu rural (centre for the promotion of agriculture and the rural environment)

${ }^{2}$ ADDEAR, Association Départementale pour le Développement de l'Emploi Agricole et Rural (departmental association for the development of agricultural and rural employment)
} 


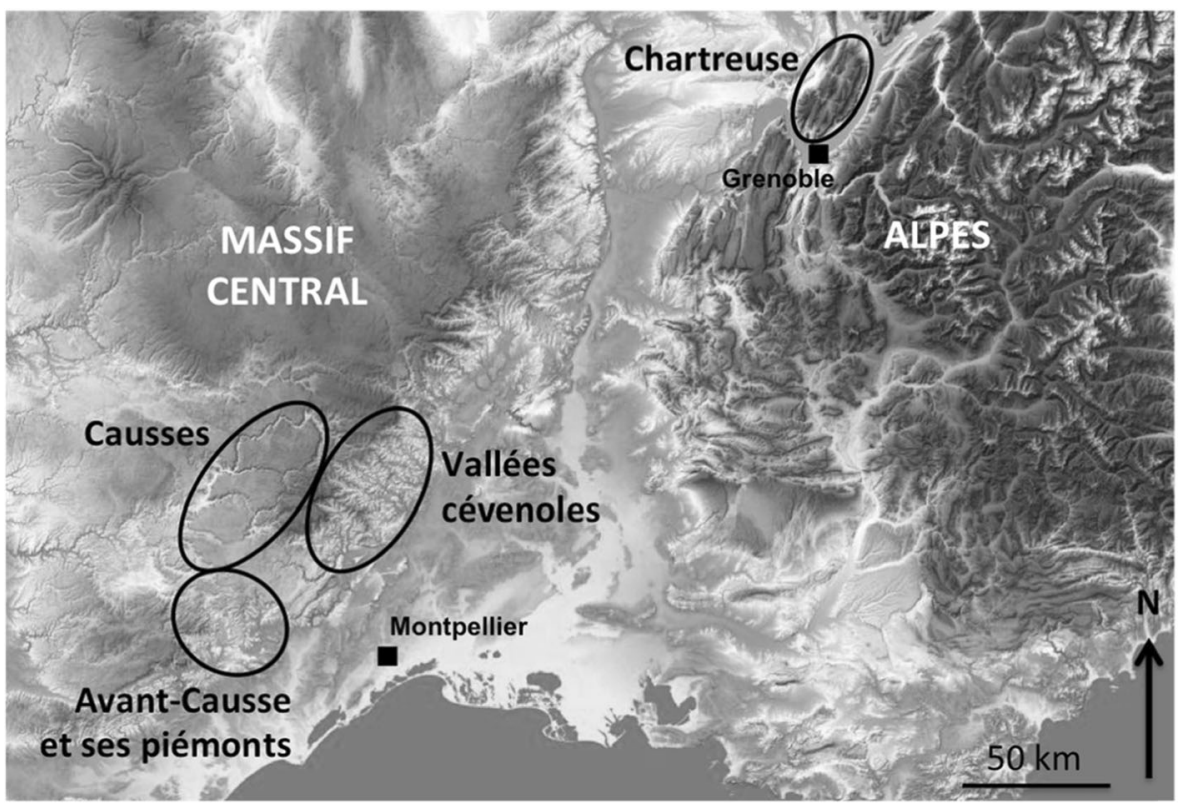

Fig. 1 Location of the four agro-pastoral regions of the study (base map from Géoportail)

between farms becomes possible. Comparison of past and present agrarian dynamics, between several small agricultural regions, also helps isolate the specificities of each of them to better highlight common mechanisms.

This comparative approach on multiple scales is based on a systemic approach using the concept of the agrarian system (Mazoyer 1987; Cochet 2012) to study the dynamics at the scale of the small agricultural region and that of the production system $^{3}$ (Reboul 1977; Cochet and Devienne 2006) (or activity system (Paul et al. 1994; Gasselin et al. 2014)) at the scale of the farm. The in-depth fieldwork carried out for this study was based in large part on the conduct of an agrarian diagnosis (Cochet and Devienne 2006; Cochet et al. 2007) in each of the four study areas (Jallot 2018; Latrille 2018; Lhoste 2018; Morsel 2018). Each agrarian diagnosis was based on 6 months of field work combining (1) a study of the landscape and its evolution; (2) an analysis of the transformation of agriculture and the differentiation of production systems (20-30 historical investigations with retired farmers in each study area); and (3) a characterization and modelling of the technical functioning of the identified production systems, through 30-50 in-depth technico-economic interviews in each study area.

The first part of this article will look at the study and comparison of the terms and consequences of the predominant agricultural development model that has been at work since the 1950s in the agro-pastoral study area, and which is focused on increasing the volume produced per worker. This first step helps better analyse and compare in the second part of this article the reasons and conditions of the parallel emergence of alternative development paths, and particularly that of frugal systems, and their reach.

\footnotetext{
3 "Production system" is understood here to mean a set of farms with similar access to resources (land: extent and type of lot; workforce: family, salaried, etc.; capital: equipment, development, etc.) and which practice the same combination of crop and livestock systems.
} 
The last part of this article discusses the limitations of coexistence between these technical and economic models which are based on different paradigms.

\section{The evolutions of agriculture in agro-pastoral regions: drivers and effects of continuous increases in physical labour productivity}

\section{In 1950, mixed crop/livestock farming marked by the predominance of spontaneous forage resources}

While they present contrasted environmental conditions, the four study areas were all home in 1950 to family farms with multiple similarities: (1) mixed crop/livestock farming focused on own consumption and the sale of surplus; (2) close relationship between livestock raising and crop farming (draught, return and transfer of fertility based on animal manuring, forage and grain consumed within the farm system); (3) many cultivation and livestock-raising operations are still manual (distribution of feed, cleaning of buildings, milking); and (4) feeding of ruminants based on grazing of largely spontaneous forage resources.

Behind this common functioning, each study area had its own specificities and main agricultural produce: small ruminants and diversified crops on partly irrigated terraces in the Cévennes valleys with their rugged terrain; dairy ewes (Avant-Causse) and goats (on its foothills), alongside grape production; cattle, mostly dairy, in Chartreuse; and dairy ewes in Causses. Woodlands and heathlands at that time played a crucial role in feeding ruminants in Cévennes, Avant-Causse and its foothills, and Causses. The complementary use of permanent pastures at different elevations, including on steep slopes, was central to the forage systems of farms in Chartreuse.

The first part of this article seeks to analyse the terms and consequences of the agricultural development model focused on increasing physical labour productivity, which, as across France, has been predominant in agro-pastoral regions for more than half a century, disrupting the mixed crop/livestock farming that prevailed in the 1950s. After detailing the drivers and mechanisms of this development for Causses, a comparison will be made between the dynamics observed in the four study areas to identify the main trends and common effects of this predominant agricultural development path. Above and beyond the emblematic agro-pastoral nature of Causses, which has been grazed by flocks of sheep for millennia, this region is of interest due to the particularly strong increase in agricultural physical labour productivity it has seen since the $1950 \mathrm{~s}$, expressed here in terms of the volume of ewe's milk and meat produced per worker.

\section{Causses: a twentyfold physical labour productivity increase since 1950, in the cradle of agro-pastoral "World Heritage"}

\section{Agriculture of the Causses limestone plateaus in 1950}

In 1950, Causses farms shared the combination of livestock farming, crops and rangelands, with very limited use of external inputs. Various animal species were raised (cattle for draught and sometimes for milk, pigs, etc.), but the development of milk collection by the Roquefort industry from the mid-19th century led to increased importance of sheep farming 
(Marres 1935; Chassany 1978). In addition to milk, which was delivered to Roquefort dairies in villages, sheep farming produced milk-lambs (less than 2 months old) and "grey lambs" raised on rangelands with their mothers up to 5 months by farms not milking all ewes (Osty 1978). Sheep farming also continued to play a major role in renewing the fertility of cultivated land through the use of manure, with fertility transferred from rangelands through keeping herds in sheepfolds at night (Chassany 1978). Lambing took place from February to March, and milking began with turn out to pasture in April and May, lasting until July. Through to December, flocks were grazed. Grazing, under the guard of a shepherd and primarily on grassy rangelands, box heathlands and scots pine woodlands (Méjean) or pubescent oak woodlands (Larzac), provided between 60 and 70\% of animals' diet (Fig. 2). Cultivable land was concentrated in areas with less steep reliefs and where soils were sufficiently deep. There was rotation between cereals, root crops, and lucerne and sainfoin to produce hay for winter feeding. While such land occupied vast and almost continuous areas in the marly limestone plateaus of the western Larzac Causse, it was much rarer and more dispersed on the dolomitic limestone of the western Méjean Causse. Along with the altitude and the climate (mountain influences to the North and Mediterranean influences to the South), this access to cultivable land was already a key differentiation factor between farms.

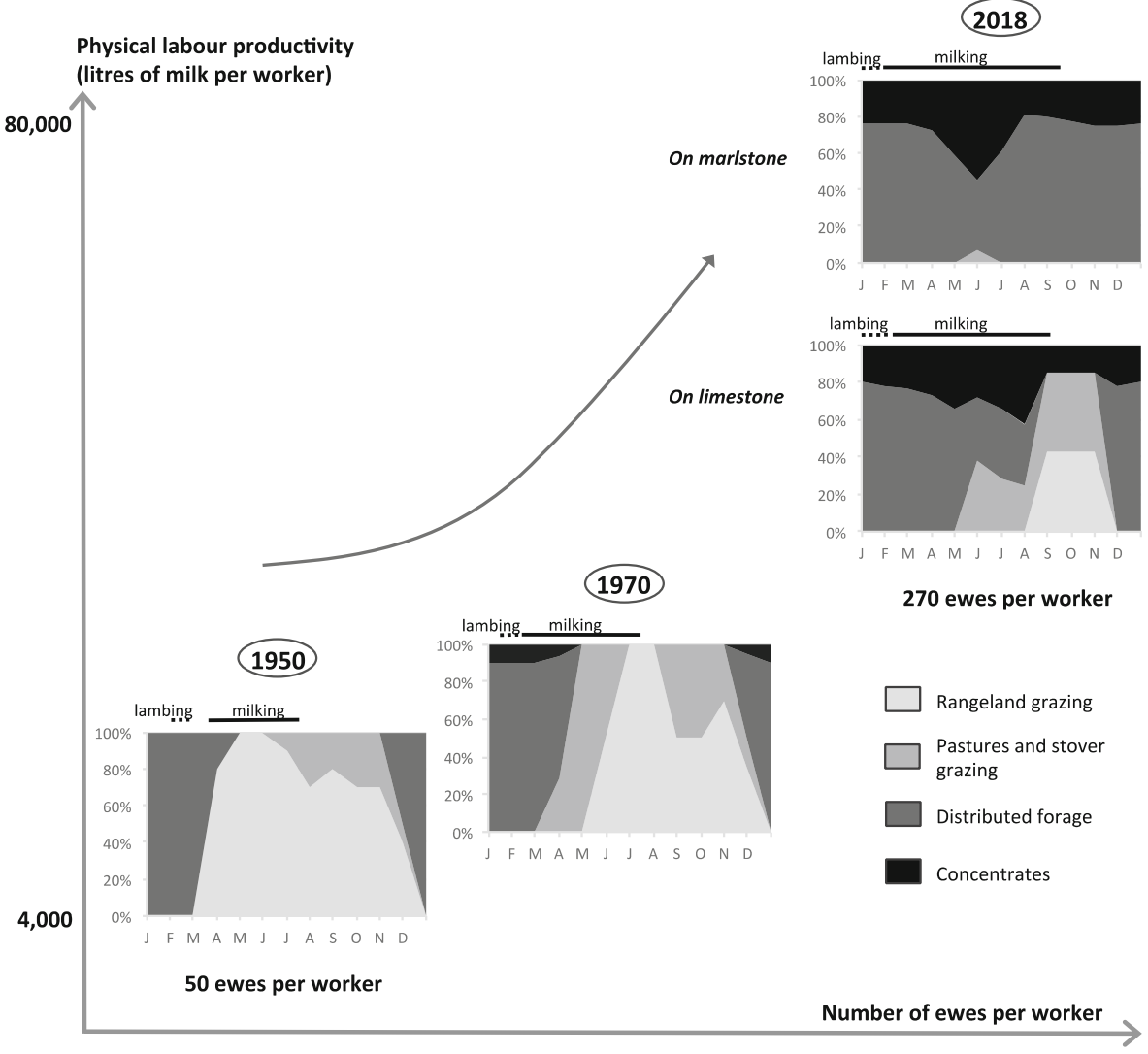

Fig. 2 Forage system and increase in physical labour productivity in Causses dairy sheep farming (data: Osty (1978) and interviews) 
Two sheep-farming specializations: the central role of temporary pastures and the fall in grazing

Two sheep-farming specializations emerged from the situation in the 1950s: dairy and suckler. Both involved an increase in the size of farms and a fundamental shift in the management of the animals (Fig. 2).

Firstly, on the farms with the most cultivable land and which specialized in raising sheep for milk, the genetic material evolved: the Lacaune ewe breed was subject to intense selection with the aim of increasing its milk yield. Temporary pastures, first sowed purely and then with mixtures, fertilized with synthetic fertilizers, and destined primarily for mowing, became the primary forage resource of the farm. Lambing having effectively been brought forward to January, milking was prolonged and now began in sheepfolds, with ewes fed on distributed feed which now represented a much larger share in the ration. Ewes continued to be taken out to graze from April to December, but this was partly done on temporary pastures in the spring, and rangelands were now used only at the end of milking (from June), or even after milk dried up (September). With the increased amount of forage produced for storage, this grazing was increasingly supplemented with a daily distribution of forage, particularly during the milking period. This limited the amount animals grazed, down to zero now on farms in marly limestone areas where this development has been pushed furthest (Fig. 2). Growing quantities of concentrates were also distributed to ewes. Initially, these were cereals produced on the farm, in rotation with meadows, and then, from the 1970s, purchased protein concentrates. Some farms, generally situated in less favourable areas and therefore producing reduced forage stocks, also began purchasing hay.

The second sheep production specialization, in suckling, concerned farms with less good-quality cultivable land or a smaller workforce than those that specialized during the same period in producing sheep's milk. They gradually began producing indoor-fed lambs ("agneaux de bergerie") which were fed in buildings using distributed feed, and fattened up more quickly than the lambs fed on rangelands in the 1950s. The share of grazing, particularly on rangelands, in the animals' feed, was greater than that practiced on dairy sheep farms, but also fell over time, giving way to stored forage.

\section{Growing fixed capital investment}

On dairy and suckler sheep farms, the technical changes presented above, and particularly the increased quantities of harvested forage distributed to larger flocks, required considerable investments. These investments initially concerned cutting equipment (tractors and mowers, followed later by the equipment for the whole hay-making process), tillage equipment, milking equipment for dairy farms, and buildings (sheepfolds and storage barns). From the 1980s, sheep farmers started acquiring rotary brush cutters to clear rangelands, as well as crushers to help reduce the time required for stone removal on cultivable land where stones regularly emerge in some parts of Causses and locally to extend cultivated plots on rangeland. More recently, some farms have also invested in moto-mechanized equipment for the distribution of feed in buildings. These developments explain why the number of ewes handled per worker has increased up to fivefold in the region over 70 years (Fig. 2). 
Even when they form joint agricultural groups (GAEC), some farms in Causses have not been able to make these investments. At each step of this moto-mechanization, some of the farms, often the smaller ones or those situated in less favourable areas, have not been passed on to the next generation when their head had retired. The land they used, particularly cultivable plots, is taken over by the farms that manage to hold up (and thus grow), illustrating the mechanism of "unequal development" identified by Mazoyer and Roudart (2006).

\section{Farm enlargement encouraged by the evolution of prices and subsidies}

The evolution of prices and agricultural policies has formed conditions conducive to the trend of increasing physical labour productivity that we have described.

Since the 1960s, the real price of sheep's milk in the Roquefort area has fallen by more than half, despite benefiting from the milk quotas system created by the Protected Designation of Origin rules to regulate production volumes between 1988 and 2015. The price of sheep meat, which was affected by the opening of competition in the European market in the late 1970s, has fallen on a similar scale over the same period. The increased quantities of milk or lambs produced per worker are a means of responding to this unfavourable evolution of price conditions, aimed at maintaining real incomes.

The 1980s and 1990s were a turning point for the Common Agricultural Policy, with the gradual termination of price-support mechanisms, increased competition and the beginning of subsidies to farmers, with the initial aim of offsetting the decline in prices (Lécole and Thoyer 2017). The productions of sheep's milk and meat, although not covered by the price policies established in 1962, became beneficiaries of these subsidies from 1980. Both animal premiums (ovine compensatory premium-PCO, later to become the ewe and goat premium-PBC, and the premium to maintain herds of suckler cows) and the payment schemes that replaced them from 2003, are based on headage or hectares, with no strict capping mechanism, encouraging Causses farms to expand. The sheep-farming support created by the French Government in 2009 is not capped either, producing the same result. The cases of the compensatory allowance for natural handicaps (ICHN) established in 1975 and of the grassland premium applicable until 2015 are a little different, in that they are capped by farm or by worker. Their payment is, moreover, subject to stocking density rules, with calculations taking into account rangeland areas. Some farms have also become beneficiaries of agroenvironmental measures (MAE), but the amounts of support received are considerably lower than under the support provision mentioned above. Following the creation of these various subsidies, some dairy sheep farms limited in the expansion of their flocks through the Roquefort quotas began additional suckler sheep or cattle production from the 1990s, making use of rangelands no longer required for dairy ewes, with limited additional labour requirements.

\section{Common effects of the predominant agricultural development model}

Since the 1950s, the agricultural development we have described for Causses, focused on increasing physical labour productivity, has resulted in common transformations in the four agro-pastoral regions of study. 


\section{Specialization of farms and reduced grazing and spontaneous vegetation in the diet of flocks}

Illustrating the analysis of the differentiation mechanisms by Mazoyer (1987), the feasibility of implementing the agricultural revolution of the second half of the 20th century has proved unequal between - and within - these regions. These inequalities are mainly based on the investment capacities of farmers and their access to cultivable land and moto-mechanizable permanent pastures, which determine an increase in forage production per hectare and an increase in the number of animals handled per worker. This explains the contrasted specialization processes between and within regions, which in all cases have seen a reduction in flock grazing, particularly on former rangelands.

In Avant-Causse, the dynamics are similar to those in Causses, except that the limited available cultivable land in Avant-Causse is offset here by access to the alluvial terraces of the neighbouring Salagou valley, encouraged by the premiums granted in the 1980s to pull up grape vines in response to excess wine production in Languedoc. As in Causses, the specialization in dairy sheep farming initially concerned the farmers with more cultivable land and with the largest farms (who otherwise moved into suckler sheep). Here too, the farming of dairy ewes has seen a fall in grazing, with the end of the use of oak and chestnut woodland, and greater use of distributed forage and concentrates.

In Cévennes, herds of small ruminants were previously led to graze every day by a shepherd, alternating between green oak and chestnut woodlands and heathlands over the course of the seasons. From the 1950s, farms with access to valley floor plots created pastures there to feed increasingly large and specialized goat herds, with milk collected and made into cheese by the Moissac cooperative created during the same period. Farms with access to heathlands or mountain grasslands, but with less motomechanizable land, specialized in suckler sheep production. While herds continued to be led to graze most of the year on woodlands, heathlands and grasslands, the share of distributed forage in their diets did grow, particularly on goat farms where farmers thus sought to increase milk yields. In this landscape with few moto-mechanizable areas, farmers also made growing purchases of forage and concentrate from other regions from the 1980s onwards.

Within the limestone range of Chartreuse, most farms completed their dairy specialization in the 1960s and 1970s. As in the 1950s, forage was solely based on the grazing of permanent pastures for 6 months of the year (May-October), supported by the use of mobile motorized milking systems, and the rest of the year, animals were fed hay from permanent pastures. There was, however, a regular increase in the share of purchased concentrates in the rations of dairy cows. These concentrates and the gradual shift from the Tarentaise to Abondance breeds suffice to explain the doubling of the milk yield per cow since the 1950 s (from 2500 to $5000 \mathrm{~L}$ per cow per year), given that stocking rate has not increased and that manuring remains strictly organic.

\section{Low value creation and dependency on subsidies}

While physical labour productivity has indeed increased under this development path, with one worker currently producing up to $80,000 \mathrm{~L}$ of sheep's milk each year in Causses (Fig. 2), the creation of value (measuring the economic productivity of labour) is today low. The high production volumes per worker are obtained at the cost of high 
consumption of inputs and expensive investments in equipment and buildings, limiting the creation of value. Figure 4 shows that, on dairy sheep farms, in the most conducive parts of Causses, value added ultimately represents $30 \%$ of the gross product, the rest being consumed in the form of inputs and fixed capital. On suckler sheep farms, in the four study areas, the gross product achieved is insufficient, under current meat price conditions in standard long supply chains, to cover intermediate- and fixed capital consumptions, despite these being lower than on dairy farms (Figs. 4 and 7). Added value is therefore negative, resulting in total dependency of these production systems on subsidies in order to produce income. Dependency on subsidies is more moderate for dairy sheep production systems in Causses, but remains high at almost 80\% (Fig. 5).

\section{Erosion of agricultural employment}

The other consequence of this development path is the erosion of agricultural employment. This erosion is not unique to the study areas. Across France, it is inseparable from the shift towards increased physical labour productivity, and results from the mechanism of unequal development mentioned above (Mazoyer and Roudart 2006; Devienne 2019). Because of less conducive conditions than on the plains for the use of the new equipment and inputs available from the 1950s, this erosion of agricultural employment was, however, stronger in agro-pastoral regions, particularly during the first decades of this movement. According to agricultural census data, the number of farms in Causses in 2010 represented around $18 \%$ of that in 1955. That figure stood at $13 \%$ in Cévennes and only $6 \%$ in the Isère Chartreuse and in the Vercors, as against $21 \%$ for mainland France as a whole for the same dates ${ }^{4}$. Where land suited to motomechanized forage production is extremely limited, livestock farming disappeared (as in the Avant-Causse foothills) and sometimes even all forms of agriculture, such as in certain very narrow valleys in Cévennes where agricultural employment is wiped out.

\section{Land abandonment and closure of landscapes}

With the fall in the role of grazing in feeding animals since 1950 in the four study areas, and its total abandonment in some areas, livestock farms are increasingly unable to curb the movement of closure of landscapes through animal farming.

In Causses, the change in the grazing management for suckler sheep farming towards large enclosures adds to this difficulty: it leads to undergrazing of less appetizing or accessible areas and has negative associated effects on biodiversity (Lepart et al. 2011). Between 1948 and 2000, 40\% of grasslands in the Méjean Causse were thus lost, replaced mostly by heathlands and spontaneous forests (Cohen 2009). In Cévennes, the very steep valleys with little rangeland at altitude, which suffer on two counts, have seen the disappearance of crop and livestock farming and a total closure of the landscape. In the Monts de Faugères and Cabrières, neighbours to the Hérault plain, the very limited motomechanizable surfaces combined with a particularly strong Mediterranean climate led to a specialization in wine production in the 1950s and the disappearance of livestock farming. The abandoned heathlands of the hills, previously grazed by goats led under the guard of a communal herder, are increasingly being overcome by woodland.

\footnotetext{
${ }^{4}$ Data from the General Agricultural Census (RGA), 2010 and 1955 (Greste)
} 

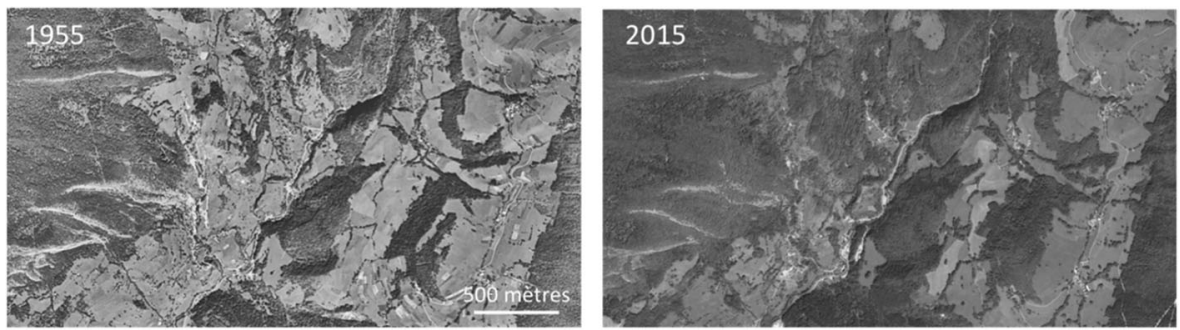

Fig. 3 Conifer afforestation since 1955 (aerial photo from 1955 and satellite image from 2015, Géoportail)

In Chartreuse, the use of a growing working width for mowing and motorized traction unsuited to the slopes explain the retreat of hay meadows to the least steep areas. As the smallest farms cease production, the larger ones grow, taking over only part of their land: the least steep plots where cutting is easy are highly sought after, while the steepest permanent pastures have gradually been abandoned. Although forests already occupied a considerable amount of the range in the first half of the twentieth century, rural exodus and reduced maintenance (by grazing or cutting) of the steepest plots have led, in some places, to a fivefold reduction in agricultural lands and particularly intense, most often spontaneous, conifer afforestation (Fig. 3).

\section{Parallel development of more sustainable alternatives in agro-pastoral regions}

\section{The enhancement of agricultural produce: the key to the viability of the less favourably situated farms?}

\section{Adherence to quality schemes with specifications}

Two protected origin labels exist in the study areas: the Roquefort PDO, which has been around a very long time (1925), covering almost all dairy sheep farms in Causses and Avant-Causse until recently, and the Pélardon PDO, which was created in 2001, covering a large part of the goat's milk production in the Cévennes valleys and Hérault foothills. In addition, since the early 2000s, many Causses farms producing sheep's milk have converted to organic farming. The first to make this transition were the smallest farms and those in the least favourable areas-massive or bedded limestone, greater climatic constraintsthat had difficulties continuing to invest and to expand their cultivable land. This development of organic dairy sheep farming came hand in hand with that of the collection of organic milk by Roquefort PDO manufacturers (Lactalis in this part of the collecting area), as well as by non-PDO companies such as the Coopérative des Bergers du Larzac. Lastly, in Chartreuse, a number of dairy producers took over the only remaining fruitière cheese dairy in the range, which was under threat and to which they had so far delivered their milk, in the form of a directly managed cooperative, with the financial support of local government (Alavoine- 
Mornas and Madelrieux 2015). The members of the cooperative chose to draw up specifications close to those of the Savoie dairy cooperatives, prohibiting the use of silage, and centred the activity of the dairy on high-quality cheeses (of the Tomme de Savoie style, but without enjoying the protected geographical indication label as the cooperative also collects milk from the Isère part of the range). The cooperative has since been joined by other dairy farmers in Chartreuse, who have abandoned their former collectors. Annual collection rose from 850,000 L in 1985 to almost 2 million L in the early 2000s.

These quality initiatives relying on specifications seek to increase the sale price of produce. Organic sheep's milk in Causses is thus one and a half times more expensive than conventional milk. The Entremonts cooperative is the last milkprocessing facility in the Chartreuse range. It offers prices higher than those practiced locally for standard milk (€445 for $1000 \mathrm{~L}$ in 2017 , as against $€ 335$ for $1000 \mathrm{~L}$ on average in the Isère department the same year, across all quality levels) ${ }^{5}$, and is a significant source of indirect jobs (cheese production and shops). The Pélardon case does, however, suggest that prices do not systematically rise with the introduction of quality initiatives with specifications. Since the creation of the Pélardon PDO, the price Moissac cooperative producers receive has not risen compared to the average national standard goat's milk price. ${ }^{6}$ For two years, it was even lower, before rising and exceeding the standard price from 2016.

\section{On-farm dairy processing}

The Orb valley and its low plateaus (Hérault), occupied by heathlands and woodlands, was, like the Cévennes valleys, reinhabited from the 1970 s by dairy goat farmers, many of whom were neorurals and lacked access to cultivable land or hay meadows. In the Hérault, the attempt to create a dairy cooperative in 1977 (Coopérative des Chevriers de l'Hérault in Lodève) ended with the bankruptcy in 1981 of the Union Laitière des Pyrénées, Aquitaine et Charente (ULPAC), to which it was affiliated. In Cévennes, many of these neorurals were too far from the Moissac cooperative, in the Vallée Française area, to supply it with milk. Today, most of the goat farmers in these two small regions therefore make their own cheeses, which they sell in short supply chains (sales on the farm, at markets and in local shops). While not all these farmers have taken the certification route, this goat farming movement was strengthened by the creation of the Pélardon PDO, which contributed to the creation of significant numbers of agricultural jobs in these areas which might otherwise have been abandoned totally. The creation in Chartreuse since the 2000s of dairy goat or sheep farms, generally set up by new entrants having no farming family background, who make cheese on the farm and sell products in short supply chains, is a similar phenomenon. Similarly, a few farms in Causses that historically delivered their milk to the Roquefort processors, and which have encountered difficulties expanding, have recently begun producing ewe's cheese.

\footnotetext{
${ }^{5}$ Data from DRAAF Auvergne Rhône-Alpes

${ }^{6}$ Data from Coopérative de Moissac and Institut de l'Élevage
} 


\section{Direct sales from suckler farms}

Starting in the 2000s, an increasing number of farms in the four regions studied with a herd of suckler ewes or cows began developing the direct sale of some of their animals. These are generally sold in the form of boxes of meat that the farmers collect from a cutting plant sometimes attached to the slaughterhouse, before delivering them to regular customers who place orders in advance. Various forms exist, depending on the specificities of the farms, in terms of product, seasonality and also distance from markets (Nozieres and Moulin 2012). For example, some farmers sell their meat in one of the many farmers' shops that they created within the regions themselves (six to date in Cévennes) and in nearby cities (Grenoble, Montpellier, etc.). Others go through associations supporting peasant farming (AMAP) or to markets. Direct sales of lamb to consumers for Eid, a practice that has emerged in the south of Cévennes, are another aspect of this shift in marketing methods. Single farms often combine several forms of sales and, in the absence of time or markets, some of the animals often continue to be sold in long supply chains through traders and cooperatives. This shift, which is labour-intensive and entails meat-cutting and marketing costs, almost doubles the sales price of animals, which is, as we have seen, particularly low.

\section{Strategies focused on higher prices without fundamentally changing the livestock practices}

While these different paths have been decisive in creating and preserving agricultural jobs, they have not, according to our study, led to a fundamental shift in the livestock practices or in the use of pastoral resources.

This is the case in existing quality initiatives with specifications in the regions studied: grazing is compulsory for the production of both Roquefort and Pélardon, but as neither set of specifications sets down rules on the balance between distributed and grazed feed, both PDOs in reality allow a small contribution of grazing to animal feed. In Causses, the shift to organic agriculture has led dairy sheep farmers to rethink fertilization, with strictly organic manuring and increased use of nitrogen-fixing pulses (forage and grains) that help reduce purchases of protein concentrates for ewes. However, with a few exceptions, large quantities of hay continue to be distributed, with grazing making up a small share of feed (between $15 \%$ and $30 \%$, almost all on temporary pastures). Hay purchases, which are now certified organic and therefore more expensive, can be considerable. In Chartreuse, where the local dairy's specifications prohibit silage and where mobile milking systems mean animals can be grazed even on land far from buildings, these rules have undeniably contributed to preserving dairy cow farms and limiting land abandonment. These specifications do not, however, limit the milk yield per cow, and have not stopped the proportion of concentrates in herds' feed from rising, or the underuse of permanent pastures unsuited to moto-mechanization or too far from farm buildings. These observations are similar to the conclusions of other studies on the ambiguous links between quality and environment initiatives (Hirczak 2011) and the fact that quality schemes fail to curb the shift to 
increased herd sizes and intensification in inputs, therefore struggling to genuinely strengthen grazing of rangelands (Aubron et al. 2014).

In the cheesemaking goat and sheep farms situated in the four regions studied, processing on the farm and sale of products in short supply chains currently form a complex system of labour- and knowledge-intensive methods. In Cévennes, most of these farms do, however, remain very dependent on bought-in hay and concentrates, and, according to our study, do not make greater use of grazing than those delivering milk to the Moissac cooperative.

Direct sales of meat are often developed on the basis of the same products that were previously sold in long supply chains (lambs, cull cows, juvenile cattle, etc.) without any real change in the animals' diet or with the addition of a fattening phase in which grazing has a limited role.

Figures 4 and 5 present the economic impact of these alternative development pathways in Causses and Cévennes. Because of the higher sales prices, gross product increases (this is less marked in the shift to organic sheep farming, as it results in a fall in milk yield). The additional gross product is, however, consumed in part through the purchases of inputs and equipment which are also increasing. The increase in value added therefore remains limited, or even non-existent for dairy sheep farming in Causses. Concerning income, the smaller size of goat farms deprives them of some of the subsidies paid to farms delivering milk, reducing their dependency on such financial support. However, this dependency does remain, and is even increasing, for organic dairy and meat-producing sheep farms developing direct sales. Subsidy dependency in Roquefort dairy sheep farming appears very high for a product under PDO, when compared, for example, to that in the Haute-Savoie department for farms producing milk for the Reblochon PDO (Aubron and Nozières-Petit 2018).

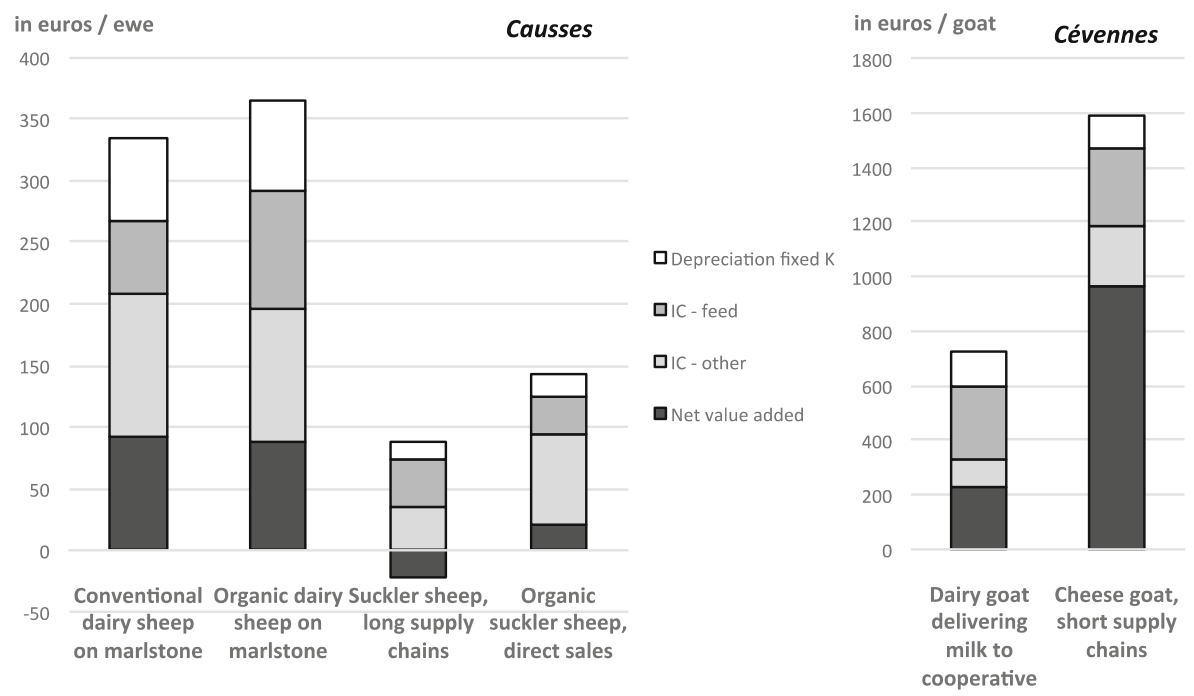

Fig. 4 Comparison of value added per worker in dairy sheep, meat sheep and dairy goat farming in Causses and Cévennes (data: interviews) 


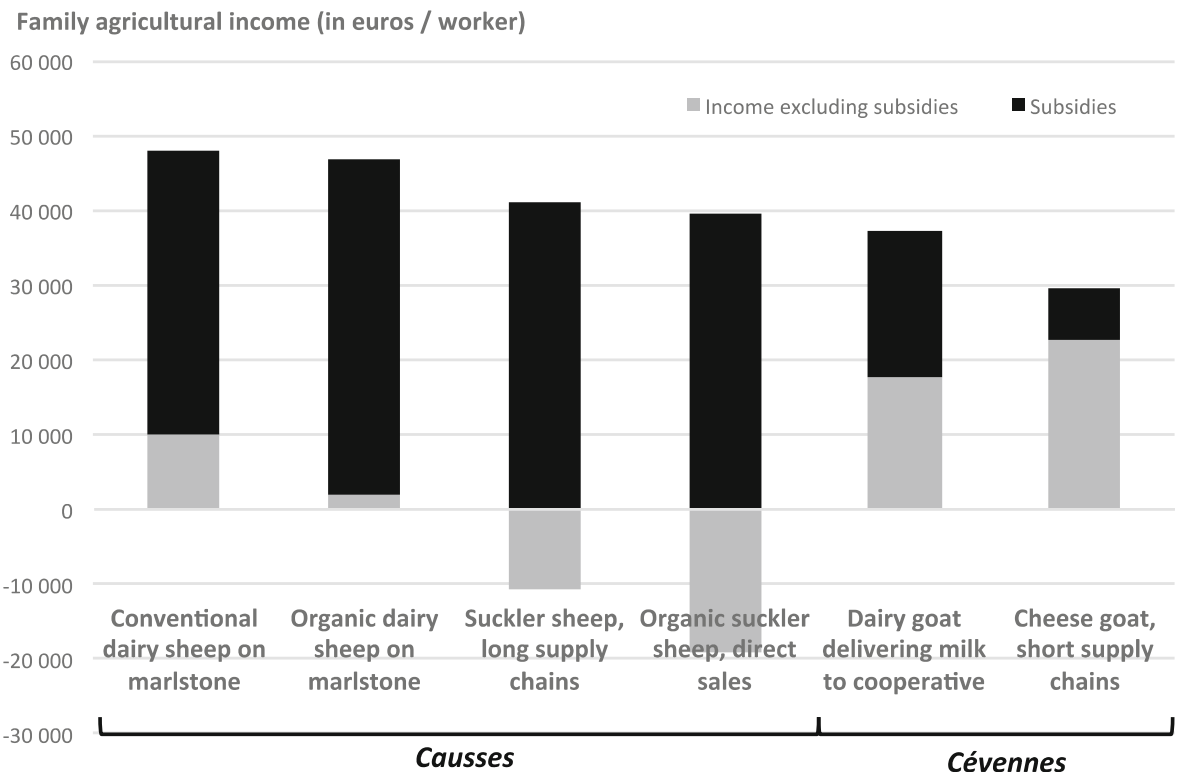

Fig. 5 Comparison of gross agricultural income per worker in dairy sheep, meat sheep and dairy goat farming in Causses and Cévennes (data: interviews)

\section{Frugal agro-pastoral systems: an unorthodox model}

Contrary to the trend of seeking higher production volumes per worker, and that of aiming to merely increase sales prices, both of which associated with a fall in grazing in the study areas, a small number of farmers have explored a different development path, based, on the contrary, on the central role of grazing in feeding the herd. This strategy aims to limit intermediate consumption and investment so as to create more wealth and agricultural jobs. To do so, they have built on the initiatives taken by other small groups of farmers in France, some of which began in the late 1950s, at that time within Centres for Agricultural Studies and Techniques (CETA) (Pochon 2008), and which later adopted the term "économe" (frugal), coined by Jacques Poly (1978), then CEO of the French National Institute for Agricultural Research (INRAE), to describe the specific logic of their production systems. ${ }^{7}$ In order to envisage the evolution of their methods together, these farmers from agro-pastoral regions themselves formed small local groups of farmers (in our case studies, CIVAM Empreinte in the Hérault and ADDEAR Isère in Chartreuse), affiliated to national networks of farmers' groups committed to alternative development paths aimed notably at preserving agricultural employment (CIVAM network and FADEAR peasant agriculture network respectively).

\footnotetext{
${ }^{7}$ In his 1978 report, Jacques Poly drew a parallel between the reduction in the workforce and an increase in production, observed a rise in the debt ratio and relative expenditure on intermediate consumption in the 1970s, and assigned a new mission to INRA: the development of techniques to "make agriculture less fragile, more frugal", "resolve the employment crisis and develop a new style of society, bringing back many jobs in our rural areas".
} 


\section{Greater use of pastoral resources}

In the last decade, these two groups, each of which include ten or so livestock farmers, based in Avant-Causse and its foothills and in Chartreuse, have gradually developed a set of techniques for grazing animals and managing grazed ecosystems, helping to provide herds with balanced feed throughout the year, based to the greatest extent possible on grazing. The complementary use of the different grazing areas (temporary pastures, permanent pastures, heathland, grassland, garrigue, woodland, etc.), adjusted to the seasonal needs of the herd, here includes more woody vegetation often left to abandon, as well as the grazing of certain crops (mixes of unripe cereals and legumes), contributing to the construction of a grazing sequence that can sometimes cover feed requirements all year. Systems that have become totally pastoral, studied in the Hérault foothills, can sometimes make use of transhumance to higher rangelands in the summer, and down to wine-growing plains in late winter. In these areas with a Mediterranean climate, where droughts can be extremely severe (early as late spring or until autumn), multi-year deferred grazing is practiced, based on certain perennial herbaceous plants (Brachypodium, etc.), shrubs (monocots, broom, etc.) and trees (ash, Phillyrea, holm oak, strawberry tree, etc.), which contributes to secure ruminants' feed (Fig. 6).

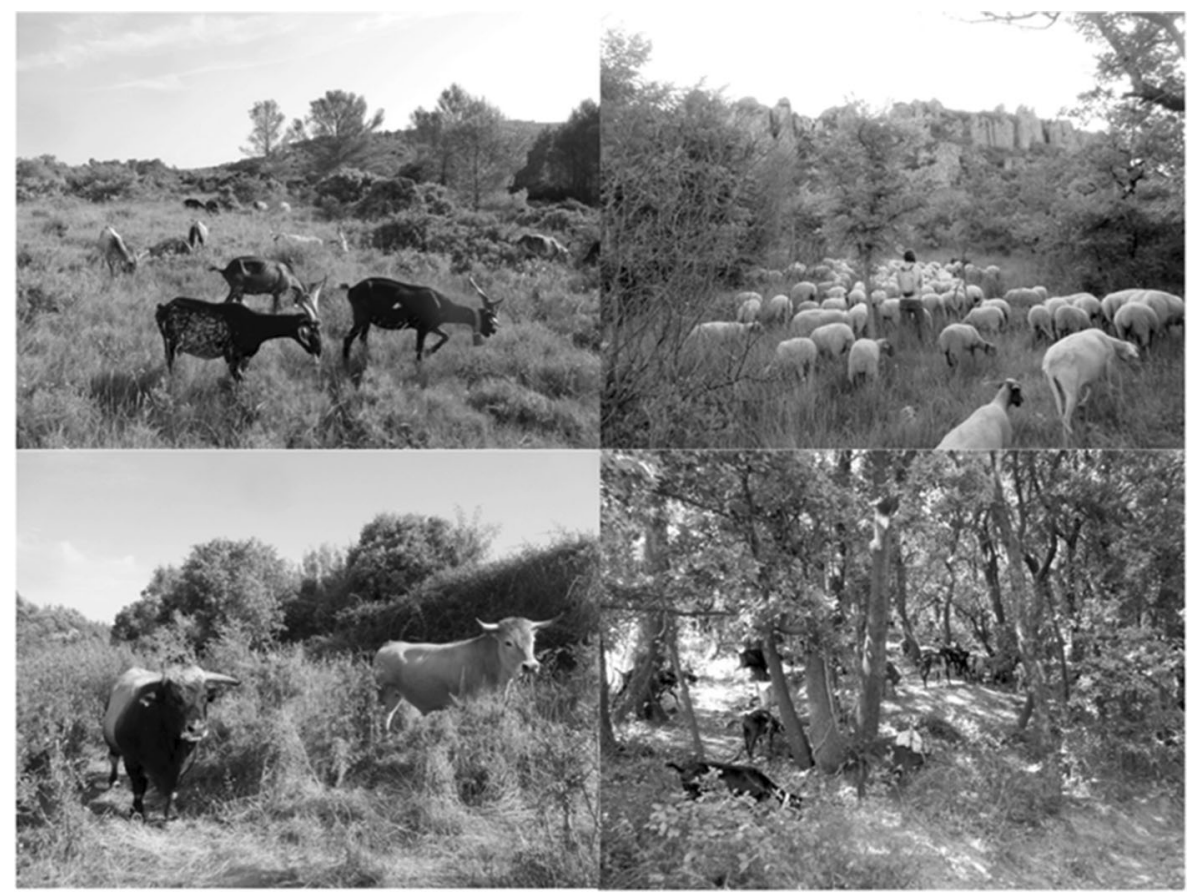

Fig. 6 Pastoral practices and the diversity of resources in frugal systems in the Hérault foothills (photography by N. Morsel) 
Rotational grazing also helps adapt the use of pastoral resources to both the rhythm of the vegetation's growth and the herd's seasonal needs. It can be based on enclosures of a suitable size (a practice used even in reverse transhumance to consume the herbaceous strata between rows of grapevines), or through guarded grazing. That last offers more mobility and makes it possible to compose feed over the course of the day, by successively grazing different types of plot, and to adapt daily duration of grazing to the herd's needs ( 8 or $9 \mathrm{~h}$ per day when very young lambs primarily feed on their mothers' milk, as against $7 \mathrm{~h}$ a day the rest of the time). The management methods for pastoral lands and grazing animals also aim explicitly to maintain diversified, highquality flora.

Making the best use of this vegetation, which is more rich in cellulose and sometimes even woody, relies on other genetic choices. More hardy breeds are capable of better using these resources. Selection of animals on the basis of their grazing aptitude, and sometimes their ability to even out the peak in lactation, in order to produce more during the grazing season. The training of grazing animals for these specific environments is crucial, encouraging high ingestion capacity in the young by familiarizing them early to enclosed or guarded grazing and ensuring they are not habituated to a feed routine, through regular changes in the grazing circuit.

\section{A frugal logic counter to the prevailing movement}

For these farmers, the increased use of grazing, making use of all available pastoral resources, seeks to reduce the quantity of forage distributed per animal and limit consumption of concentrates. In Avant-Causse, more efficient management of grazing on rangelands and the use of fern heathlands and woodlands reduce the quantity of hay consumed by dairy ewes per year by $20 \%(550 \mathrm{~kg}$ instead of $700 \mathrm{~kg}$ ), with no hay distributed from June to late October, during lactation's end and drying off periods. Grazing of chestnut woodland in autumn, when milk production dries up, and the consumption of fallen chestnuts from the floor, also help to do away with concentrates for 2 months of the year. The combination of longer lactation and its recovery in spring and summer, enabled by moderation of winter feed when lactation peaks, and savings on concentrates in autumn, helps increase annual milk yield per ewe slightly without increasing total concentrate use over the course of the year.

In Chartreuse, more efficient use of rotational grazing on permanent pastures (four rotations per year instead of three, without using synthetic fertilizers) has enabled the dairy farmers engaged in these initiatives to achieve a slightly greater stocking rate while using $25 \%$ less hay per dairy cow and per year (2.7 tons instead of 3.6 tons). The use of a more rustic breed (Tarentaise) and a 30\%-lower average milk yield (3500 L per cow per year, rather than $4900 \mathrm{~L}$ ) have also enabled these farmers to reduce concentrate distribution by more than half ( $450 \mathrm{~kg}$ per cow per year instead of a ton).

In fully grazed systems producing sheep for meat in the Hérault foothills, farmers only distribute hay on days when they want to avoid shepherding the ewes-six times less than their Avant-Causse counterparts who purchase half (50 kg of hay per ewe and per year instead of $300 \mathrm{~kg}$ ). They do not distribute 
concentrates to ewes (in part because of a lower prolificacy goal, compensated by reduced lamb mortality) and distribute half as much concentrate per lamb as in other suckler sheep production systems of Avant-Causse $(35 \mathrm{~kg}$ instead of 70 $\mathrm{kg}$ ), by doubling raising time to achieve the same weight at sale.

The reduction in intermediate consumptions associated with feeding relies not only on reducing distributed quantities but also on the methods used to produce feed. Temporary pastures combining gramineous plants and legumes can, thanks to the latter, be managed without synthetic nitrate fertilizers while offering a conducive precedent in rotation that makes it possible to reduce inputs needed for cereals. The greater (or exclusive) role of spontaneous vegetation in feeding herds, which means here no use of inputs or equipment, goes along the same lines. Reducing the use of distributed feed also helps markedly reduce the costs of purchasing forage and concentrates, and increases feeding autonomy in these farms. At the same time, by reducing animals' production objectives and keeping them outside more, farmers also save on veterinary costs. Lastly, there is a considerable reduction in fixed capital consumptions, particularly when it comes to equipment (reduction in required capacity, longer duration of use) and infrastructures to store feed. This frugal functioning is therefore not solely about increasing the feed autonomy of farms: it aims to achieve a considerable reduction in all consumption across the production system.

\section{Systems prioritizing value creation}

These "frugal" systems are characterized by a systemic reduction in costs through more intensive exploitation of the synergies between agro-pastoral land and functions specific to ecosystems, tying the model in with agro-ecology. This functioning can involve a moderation of production, where farmers often seek a new balance between production costs and the level or rhythm of production per animal (milk yield, prolificacy, average daily gain). Running counter to a trend of specializing in reproductive females, some farmers seek to de-specialize their herds, for example by switching lower-yield dairy-breed females between the dairy and suckler functions in order to increase the meat value of young (observed in dairy cow and ewe farms in Chartreuse).

Two major types of situation emerge from the analysis of the frugal systems identified in the study areas. In the first, farmers have changed their production systems' functioning, while remaining in the same sales circuits as other farmers in the area. This is the case for example for Avant-Causse dairy ewe farms delivering to Roquefort manufacturers, and for dairy cow farms delivering to the local dairy cooperative in Chartreuse. This strategy seeks to increase net value added through a greater reduction in intermediate consumptions than in gross product, while remaining aligned with the price standards for local producers. Far from being extensive, this technical and economic approach uses ecosystem resources more intensively but with reduced inputs and capital, so as to create more value and prioritize an increase in economic and not physical labour productivity. In the second, this goal of frugality in the management of the herd is combined with direct sales, sometimes with processing by the farmer (farm cheese, cutting of meat for retail, vacuum packing, etc.). This is most seen in 
regions where production conditions are relatively difficult, such as in meatproducing sheep farms, beef farms and dairy goat farms producing cheese in the Hérault foothills, and in goat's cheese and sheep meat production in Cévennes. In this case, the considerable value creation has two factors: there is an ample reduction in costs at the same time as an effort to increase the sales price, often requiring greater investment in labour (processing and sales).

Figure 7 compares the creation of net value added per head and deviations between production systems which have maintained the trend of increasing production per worker and frugal production systems focused on increasing the value created per worker. Located in similar ecosystems (but less well-endowed with cultivable land), and raising the same number of dairy ewes per worker, the frugal dairy ewe system in Avant-Causse produces per-hectare value added more than three times higher, while delivering milk at the same price. This frugal system thus preserves more than a quarter of gross product, as against less than $10 \%$ otherwise. Only farms using frugal systems currently use the heathlands and woodlands of the Hérault foothills. The strictly pastoral frugal suckler sheep farming system developed in this area can therefore only be compared with suckler sheep farming systems in other neighbouring areas featuring quite similar conditions: in this case, Avant-Causse. The number of ewes a worker can handle is identical in both locations (100-150). However, the environmental conditions are much less favourable in foothill areas (climate, vegetation, etc.). The comparison here is therefore made on a per-ewe basis and between three production systems: suckler sheep (with long channel sales), organic suckler sheep with direct sales (quite similar to the first system regarding herd's feeding, but converted in organic farming and with direct sales of produce) and frugal organic suckler sheep with direct sales (combining organic farming, direct sales and frugal functioning). With a $30 \%$ reduction in the number of lambs sold per ewe in frugal systems, the gross product is $65 \%$ higher than in sucker sheep system with long channel sales, thanks
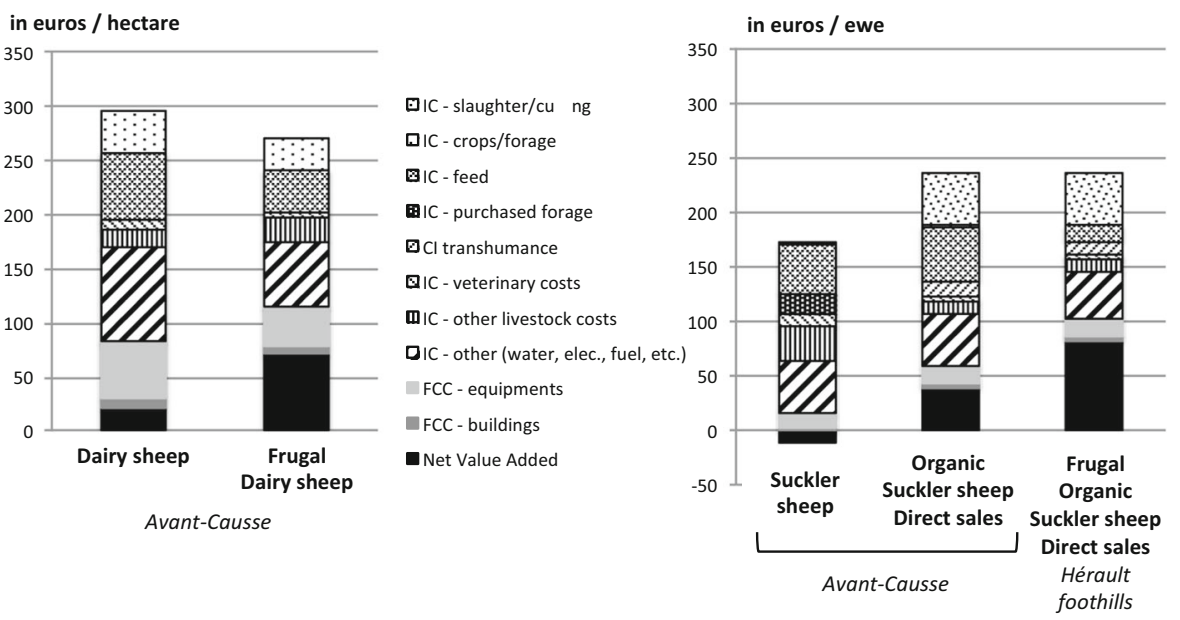

Fig. 7 Comparative formation of net value added per hectare or per head (charts: authors; data: interviews; IC, intermediate consumptions; FCC, fixed capital consumptions) 
to the higher price of lambs and cull ewes in direct sales. Intermediate- and fixed capital consumptions are limited in frugal systems: $€ 100$ per sheep (excluding slaughter and cutting costs) instead of $€ 150$ for both other systems, a difference which comes almost entirely from savings on purchased concentrates and forage. These savings allow farmers using frugal systems to retain a third of their gross product in the form of value added, whereas it would be more than entirely consumed otherwise in suckler sheep system with long channel sales (slightly negative value added), and decreased by more than $80 \%$ in organic suckler sheep with direct sales, where herd's feeding has not been deeply rethink.

The study carried out in Chartreuse produces similar results. In dairy cow farming, farms using frugal systems produced net value added per cow $20 \%$ higher than those of other dairy farms in the area, selling milk at the same price. Small ruminants farmers producing cheese themselves, who often are new entrants from a non-farming family background, systematically combine maximal use of grazing and low dependency on inputs with processing and direct sales.

\section{Frugal systems contributing more to combined preservation of jobs and landscapes}

The comparative study of the formation of agricultural income (Fig. 8) reveals equivalent income levels in frugal systems, but with less dependency on subsidies, in part thanks to the ability of these systems to maintain positive value added. These frugal systems provide farmers with similar incomes while better preserving pastoral landscapes and requiring less (or no) cultivable land, which is scarce in these areas. They also are less dependent on subsidies, while incomes from non-frugal dairy and suckler sheep systems in Avant-Causse rely wholly on support under the Common Agricultural Policy (and more than half on first-pillar payments).

\section{Family agricultural income (in euros / family worker)}

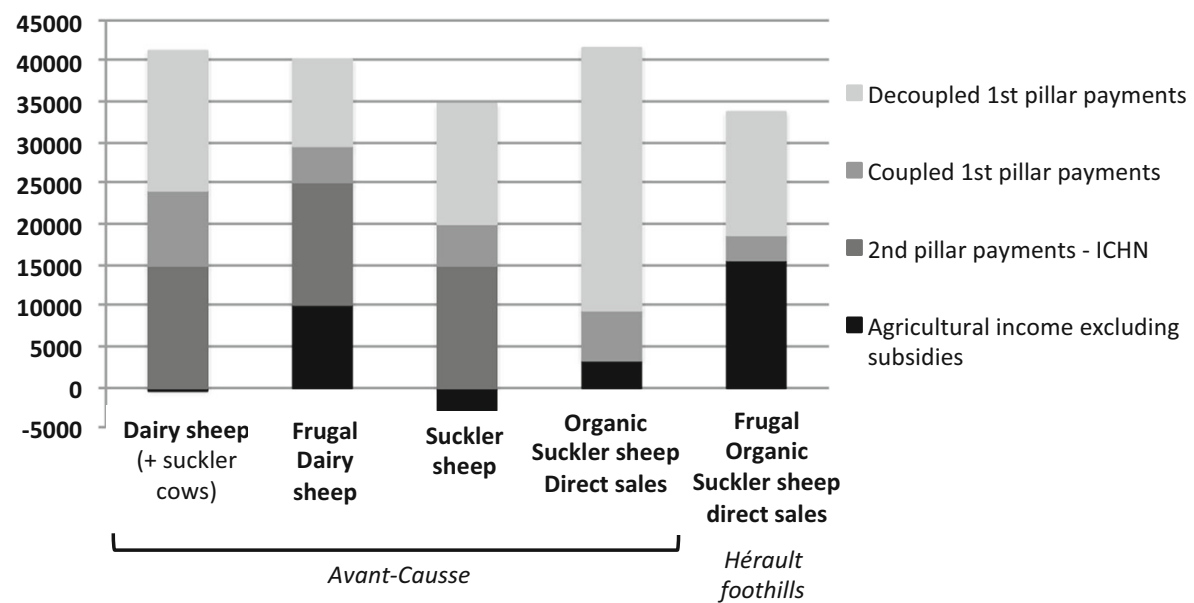

Fig. 8 Comparative composition of gross agricultural income per family worker (charts: authors; data: interviews) 


\section{The limits of coexistence: competition for resources and markets, and shortfalls in the adaptation of support services}

\section{Competition for pastoral lands eligible for CAP premiums}

Since the 1950s, three of the study areas (Causses, Avant-Causse and Chartreuse) have, like other French agricultural regions (Rapey 2016; Veysset and Delaby 2018), seen a continuous shift in dairy farming towards suckler farming, which creates less wealth and fewer jobs per hectare. While suckler herds' diet is based more on grazing than that of dairy herds, their management occupies more pastoral land with resources that tend to be increasingly underused as the size of farms and of herds increases. In parallel, the increasing size of dairy farms, a phenomenon previously seen primarily on land suitable for moto-mechanization, has expanded on pastoral areas in the last three decades. In these farms, enlargements go hand in hand with the development of small suckler cattle or sheep herds, in addition to their main activities of dairy cow or ewe farming. These suckler herds are less labour-intensive than dairy ones and more capable of consuming high-cellulose or woody resources.

Our work seems to show that the rules for first- and second-pillar Common Agricultural Policy payments have played a considerable role in this process. In Causses and Avant-Causse, the development of suckler cow farming began in the early 1990 s, most often with around 20 cows, alongside dairy ewe farming. This phenomenon came at the same time as a major increase in the "premium to maintain herds of suckler cows" (PMTVA) of 1992, while also allowing eligibility for the ICHN where the cap was not reached with dairy ewe herds. The attraction of rangeland areas was increased considerably with the 2015 reform. Indeed, following the application of a pro rata based on the degree of coverage by woody vegetation, rangelands are now included in areas eligible for basic payments. While that appears to be a positive development for the recognition of pastoral activities and areas, it has increased competition for land (Gautier 2017; Girard 2018). As Lécole and Thoyer highlight concerning area payments (2017), it is in the interests of farmers with rangelands, now eligible as such for basic payments scheme (DPB), to maintain and expand these rangelands, regardless of the use they make of them.

These suckler farmers therefore seek to use such areas while investing as little labour as possible in herding (Aubron et al. 2016). They are therefore managed in large enclosures, or sometimes without enclosures or herding, in a manner that could be described as extensive, resulting in low levels of production and value added per hectare. These areas are thus underexploited given the considerable use that can be made of them under the frugal (agro)pastoral systems we identified. Counter to such frugal systems, the underemployment of these pastoral resources means in parallel that farmers feed more their suckler herds on the basis of stored forage and concentrates, with moto-mechanized control of vegetation rather than grazing.

This process of expansion, which is currently seen across all parts of the ecosystem where eligible for premiums, therefore compounds the difficulties of access to land for farmers more focused on exploiting pastoral resources, especially those not from a farming family background, who are often in a less favourable position for accessing land. While perseverance generally pays, it might take such farmers 10 or 15 years to consolidate and secure a sufficient land base. Given limited available land, there is 
therefore a threefold problem: insufficient maintenance of pastoral areas, an overall reduction in agricultural value creation, and a fall in the number of agricultural jobs.

\section{High value added markets: a source of competition}

In the study areas, sales of agricultural products in short supply chains do not guarantee the sustainability and viability of production systems. They do not systematically result in a reduction in potentially polluting inputs, or lesser dependence on public subsidies; nor do they guarantee a strong capacity to maintain agricultural jobs, except where combined with processing activities, as is the case with goat farming in Cévennes and on the Hérault low plateaus. Without changes in the forage calendar (and sometimes even the breeds raised), purchasing products directly from the producer does not guarantee better flavour for the consumer, and can result in a number of potential constraints (grouped or seasonal purchases, time and cost of travelling to the farm). In the absence of the possibility of standing out thanks to a genuinely superior product or compliance with specifications recognized by consumers, competition and a degree of saturation on these markets, even if they remain niche, are beginning to appear for certain products (Nozières-Petit 2019). This is the case of farmhouse goat's cheese from the Hérault low plateaus and, in Chartreuse, of farmed beef sold in boxes-except if organic - despite the market opportunities offered by the relative proximity of Montpellier and Grenoble, which you might expect to be far from saturated.

Farmers who choose to combine more sustainable production systems and sales in short supply chains, and for whom this sales method is an integral part of how their farm works (higher sales price, possibility of using animals whose conformation or age at slaughter, particularly for young animals, differs from standards, etc.) therefore need to find means of overcoming this competition. To do so, they tend to focus on the taste and distinctiveness of their products, and to raise customer awareness so that they can better appreciate the positive impact of these frugal agro-pastoral farms.

\section{Significant inequality in support under the Common Agricultural Policy}

The lesser dependence on subsidies in these frugal agro-pastoral systems also underlines the current inequalities in public sector support between production systems. These inequalities can be explained first and foremost by the differences in size of the farms (agricultural surface area and headage) and support mechanisms based on headage and hectarage, some uncapped, which have been in place for nearly 40 years. Analysis of recent trends in agro-pastoral regions shows that, since the last reform of the Common Agricultural Policy (2014-2020), these inequalities have generally increased. The incorporation of rangelands into the areas eligible for basic payments, combined with a convergence of per-hectare amounts nationally, which is very favourable for such surfaces which were initially eligible for very low payments, has led to a significant increase in subsidies for farms that have large pastoral areas (Gautier 2017; Girard 2018). More flexible rules for the creation of GAECs (collective farm groupings in France) and the application of the principle of transparency in the calculation of the ICHN have had similar effects. At the same time, the fact that the ICHN is now calculated after the application of a pro rata on the area concerned has meant that some small farms using heathlands or woodlands no longer reach the cap 
and therefore receive less support than previously (Gautier 2017). These rules therefore particularly penalize workers that chose to use a limited surface area per worker by maximizing use of pastoral resources. Capping support per worker, that could be introduced thanks the upcoming CAP reform, would be a means of reducing these inequalities (Bazin and Kroll 2017).

This frugal approach, based here especially on better exploitation of woodlands and pastures, also highlights the limits of the rules for granting certain payments, such as the designation of areas eligible for ICHN support or "measures for agro-environmental and climatic conditions" (MAEC). In the Hérault department, for example, AvantCausse is wholly eligible for ICHN support, whereas it contains rangelands where the availability of forage is greater and more regular than that seen in the heathlands of the foothills, some of which were abandoned decades ago, and which have as yet not been classified as having natural handicaps. The MAEC aid "Restoration of environments opened through crushing and pastoral management", which stands at $€ 284$ per hectare annually, is paid to farmers whether they manage vegetation through moto-mechanized destruction or control of woody bushes through more sensitive, efficient management of their grazing animals. This part of the Hérault has moreover not been selected for "frugal pastoral system" MAE support, despite existing technical references. The lack of priority accorded to pastoral practices in these support mechanisms is also visible in Causses and Cévennes, where pastoral investment measures in the former LanguedocRoussillon administrative region were used to convert rangelands into temporary pastures as a measure to enhance forage autonomy (Gautier 2017). Farmers based in the Hérault and using wholly pastoral frugal systems, who feed their herds above all on the resources of heathlands and woodlands, are eligible meanwhile for no support under the second pillar of the CAP (Fig. 8).

\section{A shortfall in support from technical services}

Certain pastoral lands that have long been abandoned (woodlands and heathlands) and are not eligible for ICHN support remain on the sidelines of land concentration. Some farmers using frugal systems, who are today alone in exploiting these pastoral lands, struggle with the great number of landowners given the size of land plots (between 50 and 100 for a hill covered in heathland of around 100 ha in the Hérault foothills), which considerably complicates formal and legalized access to these ecosystems. Pro-active land consolidation projects undertaken by local councils have been limited to cultivable land and permanent pastures, whereas these long-abandoned lands have not been covered by such initiatives. Some councils have understood the benefits of ensuring maintenance of these areas, such as creating agricultural jobs and fostering social cohesion, and help farmers to formalize their access to the land and act as guarantors with regard to landowners (Guinamard and Nozières-Petit 2019). The farmers using frugal systems who currently employ these areas are, however, often forced to individually contact the multitude of small landowners to obtain their consent, or, otherwise, to graze their herds without authorization.

Moreover, the functioning principles of these frugal systems, designed not to maximize production but to seek a new balance between production and optimized use of pastoral resources, require other knowledge and expertise, as highlighted more generally in agro-ecology literature (Hubert 2013). This knowledge and expertise is 
generally based on (i) notions of ecology and botany (dynamics of spontaneous vegetation environments, knowledge of species, etc.); (ii) observation (growth rhythm of plants, state of pastoral resources, etc.); (iii) use of plant species ignored by most farmers and rustic breeds of animals which are generally less well documented scientifically; and (iv) pastoral management techniques (rotational grazing, herded grazing, etc.). Farmers are rarely trained in all these fields to begin with.

Despite key works of few technicians and scientists (Meuret 2006; Meuret and Provenza 2015; Guérin and Agreil 2007; Guérin 2008), in most cases, these farmers in frugal systems have not enjoyed the support of the major agricultural advice providers for training. The usual agricultural advice providers do not seem to have the needed technical baggage and face difficulties in setting aside the paradigm of increasing yields and production. Their approach is often considered insufficiently systemic by frugal system farmers, who consequently have established their own support and exchange groups. They have in large part taken an empirical approach to adjusting their system, including through comparisons between peers facilitated by the creation of dedicated groups and networks (CIVAM, ADDEAR, Patur'Ajust, etc.). They have also received support from associations, often based in other areas (Association Vétérinaires Éleveurs du Millavois, associations for the preservation of hardy breeds, etc.) or worked with professionals offering training in specific skills (sheepdog training, etc.). Given the diversity of pastoral resources and the technical expertise required to achieve this level of economic performance, the creation of these groups is particularly crucial for the development and dissemination of practices, the construction of suitable local technical references, and the validation of technical choices tested by several members. The role, organization and dynamics of these forms of collective action are therefore worth studying in greater depth.

\section{Conclusion: a paradigm shift in agro-pastoral farming limited to the margins?}

In the four agro-pastoral study areas, the predominance since the 1950s of an agricultural development path focused on increasing physical labour productivity has involved continuous selection of the farms most capable of carrying out the transformations required, and growing underuse of the pastoral areas deemed the most "difficult". This development path has led to particularly negative impacts, including the loss of agricultural jobs, low value added and closure of landscapes.

Alongside this predominant shift, these areas have, however, some since the 1970s, seen the emergence and development of other development pathways aimed at maintaining farms with changes in methods of sale, sometimes bringing processing activities back into the production system. While these initiatives have often helped maintain farms where conditions of access to resources were less favourable, the value created often remains limited: without fundamental changes to forage systems, the increase in gross product brought by higher sales prices for producers is offset by intermediate- and fixed capital consumptions that remain high.

A small number of farmers based in the study areas have therefore been rethinking their production systems in order to reduce costs, in some cases for almost 20 years, and most often working together in groups. These frugal systems involve an overhaul 
of all aspects of herd management, shifting towards much greater reliance on pastoral resources for feed and thus reducing the distribution of forage and concentrates. Major reductions in all key areas of expenditure, especially those related to feed, have enabled these farmers to produce much higher value added, in some cases strengthened through new sales methods and processing activities. As in plain cattle farming regions (Garambois 2011; Garambois and Devienne 2012; Devienne et al. 2018), this technical and economic approach contributes more generally to preserving jobs, while in this case particularly fostering the preservation of landscapes and maintenance of environments, including areas abandoned by most other farmers (heathlands and woodlands). These methods therefore appear to be those that contribute most to the sustainable development of agriculture in these agro-pastoral regions. Previous work on these frugal systems in plain cattle farming regions of western France, where frugal systems are most often integrated into the standard circuits for collection and processing of agricultural products, has demonstrated their greater contribution to wealth creation and employment across all sectors of activity: the high agricultural value added of frugal farms more than offsets reduced economic activity in the upstream and downstream sectors due to the more autonomous nature of these systems (Garambois 2011; Garambois and Devienne 2010). A similar analysis, also considering the economic effects on upstream and downstream activities, would be worth conducting in these agro-pastoral areas too, where a larger share of frugal systems focus on on-farm processing and direct sales.

The gradual extension of the networks enabling these frugal systems and the interest of certain neighbouring farmers, who could change their own practices, continue to have limited influence today in the agriculture of the study areas. It would be interesting to carry out more in-depth investigations into how these groups function and the specific obstacles that can exist in mid-size mountain and foothill regions, and more generally to carry out an analysis of these collective actions. Given limited resources (land, subsidies, etc.), our work shows that this coexistence is not equitable, particularly in terms of access to public subsidies and agricultural support services, which struggle to adapt to this frugal approach based on different knowledge and skills. Despite these unequal conditions for development, the longer-standing networks bringing together farmers using frugal systems in plain cattle farming regions of western France demonstrate the ability of such groups of farmers to continually increase their value added, to ensure long-term viability, to pass on their farms and to maintain more agricultural jobs in the long term (Garambois 2011). Although they formed more recently, groups in mid-size mountain and foothill regions are seeing similar momentum, with relative growth compared to other farms whose numbers and employment are falling more quickly. The issue of workload within these frugal systems is worth studying in greater depth, particularly on farms where they are based on guarded grazing (so with unavoidable daily work) and where these systems are combined with on-farm processing and direct sales. However, above and beyond mere volume of work, farmers involved in these frugal efforts highlight the different nature of agricultural tasks and the fact that they make use of skills which are often absent from agricultural training (Blondel and Gomès 2019).

Given the inexorable collapse of agricultural employment and the increasing closure of landscapes in these agro-pastoral regions, can the marginal co-existence of these systems and gradual spread of their practices be considered sufficient? It is clear that the 
authorities have not sufficiently seized upon the paradigm shift represented by these frugal systems or the levers they can play on with the aim of significantly pushing the agricultural development model of these agro-pastoral regions towards greater sustainability. As previous work on these frugal systems in other French regions has shown (Devienne et al. 2018), these levers concern all dimensions of agricultural policies, from agricultural training and advice through to access to land (role of Regional Land Development and Rural Establishment Companies-SAFER and local authorities) and support provision through the CAP. On top of such levers, access to agricultural and food product markets, including through the relocation of food systems, such as in the framework of the Territorial Food Programmes (PAT) currently being developed, is also important for these frugal systems involving on-farm production and direct sales in agro-pastoral regions. The challenge then above all concerns the scale of the support that the authorities can or cannot provide to such initiatives, which prepare the ground for more sustainable agriculture.

Funding information This work was carried out under a project funded by the Fondation de France and conducted in collaboration with national associations-Association Française de Pastoralisme and CIVAM network - and local farmers' associations: CIVAM Empreinte (Hérault department) and ADDEAR Isère (Isère department).

\section{References}

Alavoine-Mornas, F., \& Madelrieux, S. (2015). Coopératives laitières: facteurs de maintien de l'élevage laitier en montagne ? Revue de Géographie Alpine, 103-1, online.

Aubron, C., Nozières-Petit, M.-O. (2018). Dynamiques laitières en Haute-Savoie, L'AOP Reblochon au service du développement du territoire ? Rapport d'une étude conduite avec les étudiants de Montpellier SupAgro. https://www.supagro.fr/ebooks/extranet/2018-SupAgro_Dynamiques_laitieres_ Haute-Savoie.pdf

Aubron, C., Peglion, M., Nozières, M.-O., Boutonnet, J.-P. (2014). Quality schemes and pastoralism in France. Synergies and paradoxes. Journal of Alpine Research | Revue de Géographie Alpine, 102-2, online.

Aubron, C., Noël, L., \& Lasseur, J. (2016). Labor as a driver of changes in herd feeding patterns: evidence from a diachronic approach in Mediterranean France and lessons for agroecology. Ecological Economics, $127,68-79$.

Bazin, G., \& Kroll, J.-C. (2017). Jusqu'où faut-il « renationaliser » la PAC ? Economie Rurale, 362, 91-98.

Blondel, L., \& Gomès, D. (2019). Les systèmes agropastoraux économes. Quelles modalités et conditions de mise en œuvre ? Synthèse de la table ronde. In L'économie des régions agro-pastorales revisitée. Formes et conditions de développement de systèmes agropastoraux conciliant création de richesse et d'emplois et entretien des écosystèmes (pp. 69-73). Pastum hors-série: Association Française de Pastoralisme et Cardère éditeur.

Charroin, T., Veysset, P., Devienne, S., Fromont, J. L., Palazon, R., \& Ferrand, M. (2012). Productivité du travail et économie en élevages d'herbivores: définition des concepts, analyse et enjeux. Productions Animales, 25, 193-210.

Chassany, J. P. (1978). Le Causse Méjean. INRA-ESR, Paris, France: Elements d'histoire agro-ecologique.

Cochet, H. (2012). The système agraire concept in francophone peasant studies. Geoforum, 43, 128-136.

Cochet, H. (2015). Comparative agriculture. Springer.

Cochet, H., \& Devienne, S. (2006). Fonctionnement et performances économiques des systèmes de production agricole: une démarche à l'échelle régionale. Cahiers agricultures, 15, 578-583.

Cochet, H., Devienne, S., \& Dufumier, M. (2007). L'agriculture comparée, une discipline de synthèse ? Économie rurale, 297-298, 99-112.

Cohen, M. (2009). Le Causse Méjean et l'embroussaillement. Parc national des Cévennes. 
Devienne, S. (2019). Les révolutions agricoles contemporaines en France. In Chouquer G., Maurel M.-C., dir., Les mutations récentes du foncier et des agricultures en Europe (pp. 21-52). Presses Universitaires de Franche-Comté.

Devienne, S., Garambois, N., Perrot, C., Dieulot, R., \& Depeyrot, J.-N. (2018). Les exploitations d'élevage économes et autonomes, fortes créatrices de valeur ajoutée. CEP-MAA, Analyse, 126.

Galliano, D., Lallau, B., \& Touzard, J.-M. (2017). Coexistences et transitions dans l'agriculture. Revue française de socio-économie, 2017-1, 23-30.

Garambois, N. (2011). Des prairies et des hommes: agro-écologie, création de richesse et emploi en élevage bovin, Thèse de doctorat, AgroParisTech.

Garambois, N., \& Devienne, S. (2010). Evaluation économique, du point de vue de la collectivité, des systèmes bovins laitiers herbagers, 17e journées Rencontres de la Recherche autour des Ruminants, INRA/Institut de l'Elevage, 8 et 9 décembre 2010. http://www.journees3r.fr/IMG/pdf/2010_01_02_ Garambois.pdf.

Garambois, N., \& Devienne, S. (2012). Les systèmes herbagers économes. Une alternative de développement agricole pour l'élevage bovin laitier dans le Bocage vendéen? Économie rurale, 56-72.

Gasselin, P., Vaillant, M., \& Bathfield, B. (2014). Le système d'activité. Retour sur un concept pour étudier l'agriculture en famille, in Gasselin P., Choisis J.P., Petit S., Purseigle F., Zasser S., dir., L'agriculture en famille: travailler, réinventer, transmettre. EDP Sciences, 101-22.

Gautier, G. (2017). Influence de la Politique agricole commune sur les pratiques pastorales des Causses et des Cévennes. Rapport de thèse professionnelle pour le master PAPDD AgroParisTech. http://draaf.occitanie. agriculture.gouv.fr/IMG/pdf/rapport_gg_version_170703_cle011c56.pdf.

Girard, N. (2018). L'impact de la réforme PAC sur les systèmes d'élevage en montagne, Politiques agricoles et alimentaires: trajectoires et réformes. Symposium, Montpellier.

Guérin, G. (2008). De la forêt pâturée au sylvopastoralisme. Forêt méditerranéenne XXIX, 4, 491-496.

Guérin, G., \& Agreil, C. (2007). Qualifier les surfaces pastorales pour combiner le renouvellement des ressources alimentaires et la maîtrise des couverts végétaux. Acquis, enjeux et questions actuelles, Actes des Rencontres Recherche Ruminants, 2007(14), 145-152.

Guinamard, C., Nozières-Petit, M.-O. (2019). Diversité des formes d'installation en élevage dans les territoires méditerranéens. Institut de l'Elevage.

Hirczak, M. (2011). L'interrelation complexe entre signes de qualité et environnement en France. Norois, 219, $75-88$.

Hubert, B. (2013). L'agroécologie : une mise en tension de la pensée agronomique? In Goulet F., Madga V., Girard N., Hernandez V. (dir.), L'agroécologie en Argentine et En France: regards croisés. Editions L'Harmattan, 121-150.

Jallot, L. (2018). Diagnostic agraire dans le Massif de la Chartreuse. Mémoire d'ingénieur AgroParisTech.

Latrille, M. (2018). Diagnostic Agraire de la région des Causses. Les systèmes économes et autonomes en région de piémont et de moyenne montagne. Mémoire d'ingénieur Montpellier SupAgro.

Le Velly, R. (2017). Dynamiques des systèmes alimentaires alternatifs, In Lubello P., Falque A., Temri L., dir., Systèmes agroalimentaires en transition. Editions Quae, 149-158.

Lécole, P., \& Thoyer, S. (2017). La PAC et l'environnement: freins et leviers pour la transition agroécologique. In Lubello P., Falque A., Temri L., dir., Systèmes agroalimentaires en transition. Editions Quae, 51-70.

Lepart, J., Marty, P., \& Fonderflick, J. (2011). Dynamique des paysages agro-pastoraux des Causses et biodiversité. Fourrages, 208, 343-352.

Lhoste, V. (2018). Effets des systèmes d'élevage économes et autonomes de moyennes montagnes sur l'emploi, les paysages et les systèmes alimentaires. Etude diagnostic agraire des vallées cévenoles. Mémoire d'ingénieur Montpellier SupAgro.

MacDonald, D., Crabtree, J. R., Wiesinger, G., Dax, T., Stamou, N., Fleury, P., Gutierrez Lazpita, J., \& Gibon, A. (2000). Agricultural abandonment in mountain areas of Europe: environmental consequences and policy response. Journal of Environmental Management, 59, 47-69.

Marres, P. (1935). Les Grands Causses: étude de géographie physique et humaine. Arrault et cie.

Mazoyer, M. (1987). Dynamiques des systèmes agraires: rapport de synthèse présenté au Comité des systèmes agraires. Ministère de la Recherche et de la Technologie.

Mazoyer, M., \& Roudart, L. (2006). A history of world agriculture: from the neolithic age to the current crisis. NYU Press.

Meuret, M. (2006). Les pratiques pastorales entre temps court de l'alimentation des troupeaux et temps long des ressources et des milieux, Académie d'Agriculture de France, Séance du 31 mai 2006.

Meuret, M., \& Provenza, F. D. (2015). When art and science meet: integrating knowledge of French herders with science of foraging behavior. Rangeland Ecology \& Management, 68, 1-17. 
Morsel, N. (2018). Analyse-diagnostic du système agraire des hautes vallées de l'Orb et du Lodévois et de leurs piémonts. Mémoire d'ingénieur AgroParisTech.

Nozieres, M.-O., \& Moulin, C.-H. (2012). Quelles formes de vente directe des agneaux en Languedoc Roussillon? Rencontres autour des Recherches sur les Ruminants, 19, 306.

Nozières-Petit, M.-O. (2019). Quels marchés pour valoriser les produits des systèmes agro-pastoraux ? In Aubron C., Garambois N, Nozières-Petit M.O., dir., L'économie des régions agro-pastorales revisitée. Formes et conditions de développement de systèmes agropastoraux conciliant création de richesse et d'emplois et entretien des écosystèmes. Association Française de Pastoralisme et Cardère éditeur, 77-86.

Osty, P.-L. (1978). Pratiques d'élevage et paysages du Causse Méjan. Economie rurale, 128, 15-22.

Paul, J.-L., Bory, A., Bellande, A., Garganta, E., \& Fabri, A. (1994). Quel système de référence pour la prise en compte de la rationalité de l'agriculteur: du système de production agricole au système d'activité. Les Cahiers de la recherche développement, 39, 7-19.

Pochon, A. (2008). Agronomes et paysans, un dialogue fructueux. Editions Quae.

Poly, J. (1978). Pour une agriculture plus économe et plus autonome. INRA.

Rapey, H. (2016). Multiple forms of mountain-area dairy farms converting from milk to meat. Case study in the Massif Central. Journal of Alpine Research | Revue de Géographie Alpine, 104-4, online.

Reboul, C. (1977). Déterminants sociaux de la fertilité des sols. Fertilité agronomique et fertilité économique. , Actes de la Recherche en Sciences Sociales, 17-18, 85-112.

Veysset, P., \& Delaby, L. (2018). Diversité des systèmes de production et des filières bovines en France. Innovations Agronomiques, INRA, 68, 129-150.

Publisher's note Springer Nature remains neutral with regard to jurisdictional claims in published maps and institutional affiliations. 